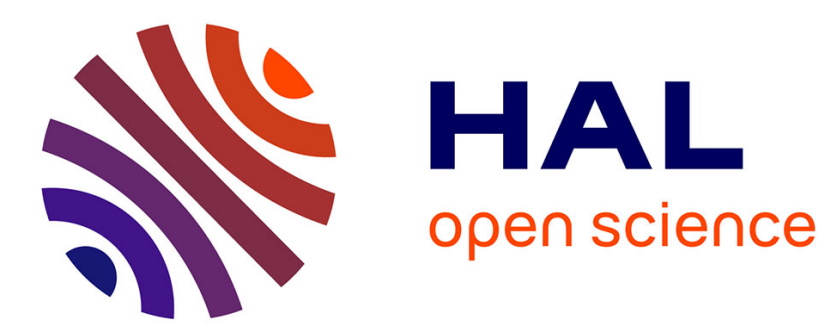

\title{
SHORT-RANGE ORDER AND THERMODYNAMIC BEHAVIOUR OF Pd-Si MELTS
}

Claire Bergman, R. Chastel, M. Gilbert, R. Castanet, J. Mathieu

\section{To cite this version:}

Claire Bergman, R. Chastel, M. Gilbert, R. Castanet, J. Mathieu. SHORT-RANGE ORDER AND THERMODYNAMIC BEHAVIOUR OF Pd-Si MELTS. Journal de Physique Colloques, 1980, 41 (C8), pp.C8-591-C8-594. 10.1051/jphyscol:19808150 jpa-00220250

\section{HAL Id: jpa-00220250 https://hal.science/jpa-00220250}

Submitted on 1 Jan 1980

HAL is a multi-disciplinary open access archive for the deposit and dissemination of scientific research documents, whether they are published or not. The documents may come from teaching and research institutions in France or abroad, or from public or private research centers.
L'archive ouverte pluridisciplinaire HAL, est destinée au dépôt et à la diffusion de documents scientifiques de niveau recherche, publiés ou non, émanant des établissements d'enseignement et de recherche français ou étrangers, des laboratoires publics ou privés. 


\title{
SHORT-RANGE ORDER AND THERMODYNAMIC BEHAVIOUR OF Pd-Si MELTS
}

\author{
C. Bergman, R. Chaste1, M. Gilbert, R. Castanet and J.C. Mathieu
}

Centre de Thermodynamique et de Microcalorimétrie du C.N.R.S., 26, rue du 141e R.I.A., 13003 Marseilze, France.

\begin{abstract}
In this work, as in our previous works on meta1-silicon liquid alloys $(1,2,3)$, we have studied the strong interactions existing in these melts and how these effects can interfere with the thermodynamic behaviour. Besides, it can be asked if the deep eutectic present in these melts is related to the existence of chemical interactions leading to the observed high stability of the liquid phase. This point is of particular interest, connected with the understanding of the structure and the thermal stability of amorphous materials.
\end{abstract}

\section{EXPERIMENTAL}

The enthalpy of formation of liquid Pd-Si alloys was measured by direct reaction calorimetry at $1380 \mathrm{~K}$ using a Calvet high-temperature calorimeter (4). Since Pd and Si melt at high temperature, the samples in the cell were master alloys, prepared outside of the calorimeter. The measurements have been performed in the two eutectic regions (Fig. 1) on both sides of the compounds $\mathrm{Pd}_{2} \mathrm{Si}$ $\left(T^{m}=1671 \mathrm{~K}-\mathrm{s}\right.$.

The partial molar enthalpies of Pd and Si $h_{P d}^{f}$ and $h_{S i}^{f}$ can be readily calculated with reference

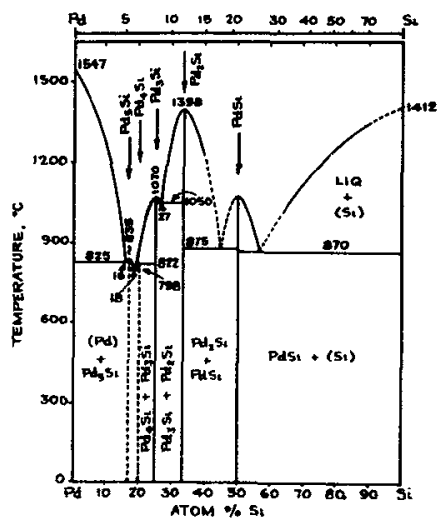

FiG. 1

to pure solid components from the measured heat effects and the enthalpy changes of pure metals from To to $1380 \mathrm{~K}(5)$.

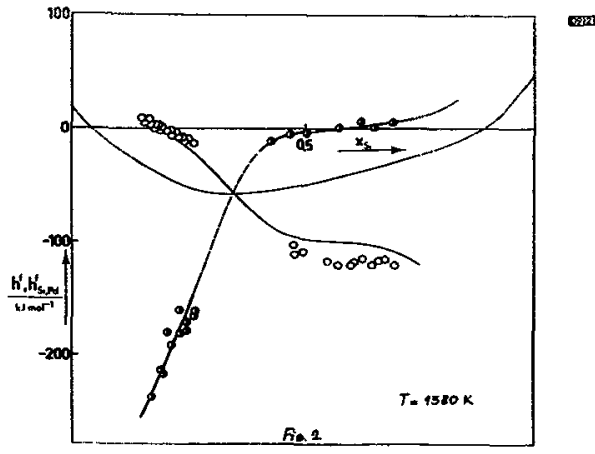

The results obtained in this way are shown on Fig. 2 as well as the calculated integral molar enthalpy of formation, $h^{f}$. We can see that the $h_{\mathrm{Pd}}^{f}-$ values calculated from $h_{S i}^{f}$ using the Gibbs-Duhem relation do not quite agree with the experimerfal ones. Fig. 3 shows the $h^{f}$ values referred to both liquid components ; $\mathrm{h}^{f}$ is strongly negative with a minimum, $-87 \mathrm{~kJ} \mathrm{~mol}^{-1}$, at $x_{S i} \equiv x=0.37$. The results of VATOLIN et aZ. (6), obtained also by calorimetry yield $h_{\mathrm{min}}^{f}=-56 \mathrm{~kJ} \mathrm{~mol}^{-1}$ at $x=0.35$ but at $1838 \mathrm{~K}$.

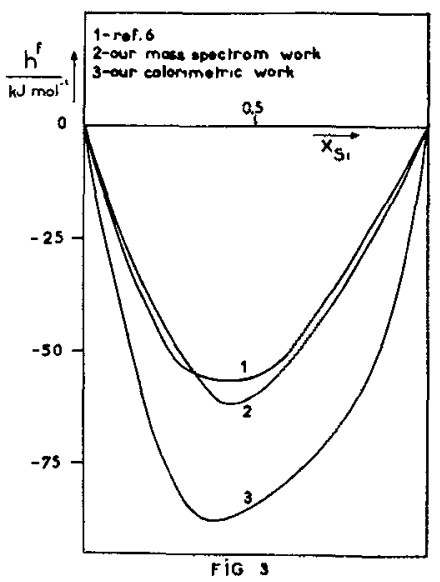


In arder to determine the Gibbs energy of formation of the Pd-Si melts, we used the knudsen effusion method combined with a mass spectrometer $(7,8)$. Three different procedures were employed ac cording to the ranges of temperature and concentration :

a) measurements of the vapour pressure ratio of Pd and Si according to reference ( 9 ),

b) investigation of the equilibrium

$$
\mathrm{Si}_{2}(\mathrm{~g}) \neq 2 \mathrm{Si}(\mathrm{g}) \quad(10)
$$

c) meesurements of the vapour pressure of $\mathrm{Pd}$ and Si above the melt and pure metals during the same experiment. In this case, pure metals placed in the same cell are solid at low temperature and thus do not react before melting.

21 different concentrations were investigated in the temperature range $1750-2000 \mathrm{~K}$. Fig. 4 enables the comparison between our results and those of VATOLIN et az. (11) obtained by e.m.f. at $1873 \mathrm{~K}$ and those of BOWLES et $a$. (12) obtained by an equilibrium method at $1833 \mathrm{~K}$ as compiled by CHART (13).

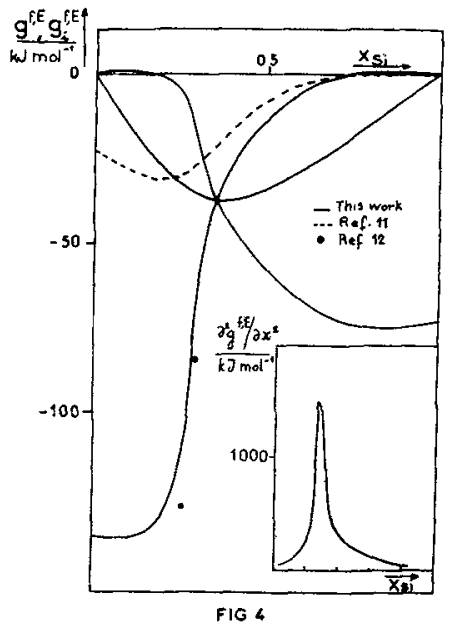

Our results yield the molar integral excess Gibbs energy of formation, $g^{f, E}$, referred to both pure liquid components having a minimum of $-38.1 \mathrm{~kJ} \mathrm{~mol}^{-1}$ at $x=0.35$ at the mean temperature $\mathrm{T}_{\mathrm{s}}=1830 \mathrm{~K}$.

From our spectrometric measurements, we deduced also the enthalpies of formation of the melt (Fig. 3). They agree well with the reference (6) $(T=1838 \mathrm{~K})$. They lead to a minimum of $-61 \mathrm{~kJ} \mathrm{~mol}^{-1}$ instead of $-56 \mathrm{~kJ} \mathrm{~mol}^{-1}$ (G) roughly at the same molar fraction.
From the two sets of calorimetric results, the excess heat capacity, $C \mathrm{C}^{E}$, of the liquid alloys, can be calculated. $C_{p} E$ is strongly positive, with a maximum of $60 \mathrm{~J} \mathrm{~mol}^{-1} \mathrm{~K}^{-1}$. The dependence of $\mathrm{s}^{f}$, deduced from the measurements of $g^{f}$ at $1830 K$ and $h^{f}$ at $1838 K$ (6) with the molar fraction is shown in Fig. 7 ; $s^{f}$ is negative and presents two minima at $x=0.25\left[s^{f}=-5.8 \mathrm{~J} \mathrm{~mol}{ }^{-1} K^{-1}\right)$ and at $x=0.55$ $\left[\mathrm{s}^{f}=-6.7 \mathrm{~J} \mathrm{~mol}^{-1} \mathrm{~K}^{-1}\right)$; this negative value indicates a strong contribution from others effects than the configurational one.

\section{STRUCTURE OF THE MELT}

The themodynamic behaviour of the Pd-Si melts is characterized by large negative deviations from ideality. This behaviour cannot be interpreted without assuming that Pd and Si atoms interact in the melt to give chemical bonding i.e. heteraclustering (associations with large lifetime). When temperature increases, the stability of the heteroclusters decreases corresponding to a dissociation of them and thus to a less negative enthalpy of formation $\left[C_{p} E>0\right)$.

Now the question arises : what is the stoechiometry of the associations in the liquid state? In many cases, clusters correspond to a congruently melting compound as $\mathrm{Bi}_{2} \mathrm{Mg}_{3}$ in $\mathrm{Bi}-\mathrm{Mg}, \mathrm{Ag}_{2} \mathrm{Te}$ in $\mathrm{Ag}-\mathrm{Te}$ ... Here, four congruently melting compounds are present. Then, considering an ideal associated model i.e. assuming that the melt can be treated as an ideal ternary system where the species are $P d$, Si and $\mathrm{Pd}_{\mathrm{y}} \mathrm{Si}(\mathrm{y}=1,2,3$ or 4$)$, we tried to represent the thermodynamic functions of the Iiquid.

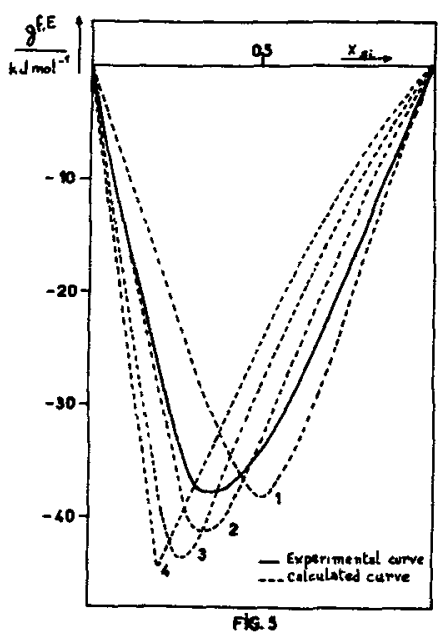


The results concerning $g^{f, E}$ are shown on Fig. 5 ; the curves are noted $1,2,3,4$ according to PdSi, $\mathrm{Pd}_{2} \mathrm{Si}, \mathrm{Pd}_{3} \mathrm{Si}$ and $\mathrm{Pd}_{4} \mathrm{Si}$. It can be seen that the agreement between experimental and calculated values is poor, especially concerning the location of the minimum. The use of interaction parameters between the different species present in the melt do not improve satisfactorily the fit.

However, in the case of $\mathrm{Pd}_{2} \mathrm{Si}$ and $\mathrm{Pd}_{3} \mathrm{Si}$, the location of the calculated minimum should be shifted toward the Si-rich side to improve the agreement. Then, a more sophisticated representation of the melt was achieved, using a two clusters based model, according to the two minima of the entropy of formation ; two possibilities were considered : PdSi and $\mathrm{Pd}_{2} \mathrm{Si}$ or PdSi and $\mathrm{Pd}_{3} \mathrm{Si}$. The results obtained in this way are represented on Fig. 6 concerning $g^{f, E}$; The agreement is much better than with one cluster. Fig. 7 shows the entropy of formation, $s^{f}$, as well as the entropy of configuration, $s^{\text {conf }}$. The peculiar shape of $s^{f}$ (two minima) is due to $s^{\text {conf }}$ calculated assuming that the clusters accupy several

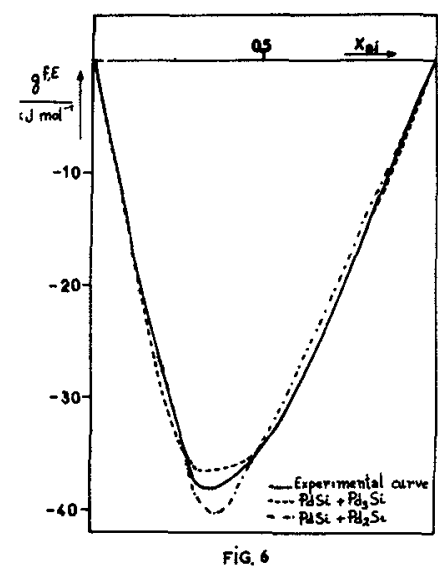

sites of the quasi-lattice, i.e. we did not take into account the permutations between polyatomic and monoatomic species to calculate the number of complexions.

The comparison between the two sets of calculated results ( $\mathrm{PdSi}-\mathrm{Pd}_{2} \mathrm{Si}$ and $\mathrm{PdSi}-\mathrm{Pd}_{3} \mathrm{Si}$ ) and the experimental ones seems to be more favourable to the presence of PdSi-Pd 3 Si. This fact can be compared to neutron or RX-diffraction measurements performed on amorphous and liquid Pd-Si samples $(14,15,16)$; their interpretation from a

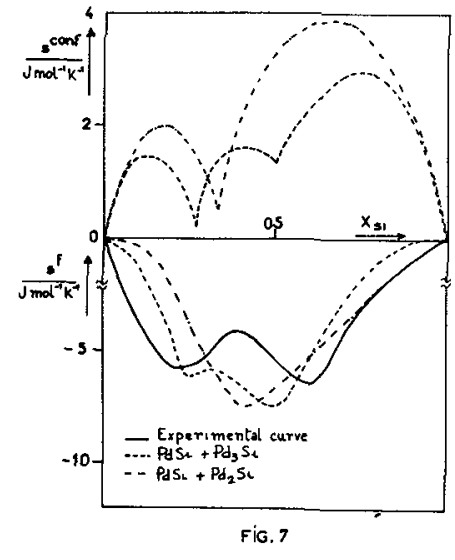

structural point of view, enables the construction of models based on the unit-cell of the $\mathrm{Pd}_{3} \mathrm{Si}$ crystal. Furthermore, the curve of the excess stability function of DARKEN (Fig. 4) from our measurements presents a strong maximum at $x=0.275$. The lack of a similar peak at $x=0.5$ can be explained by the weaker stability of the PdSi species towards the $\mathrm{Pd}_{3} \mathrm{Si}$ species as confirmed by the values of the association constants

$K\left[\mathrm{Pd}_{3} \mathrm{Si}\right)=95000$ associated to $\Delta \mathrm{H}^{\mathrm{O}}\left(\mathrm{Pd}_{3} \mathrm{Si}\right)=$ - $221 \mathrm{~kJ} \mathrm{~mol}^{-1}$, and $\mathrm{K}(\mathrm{PdSi})=300$ associated to $\Delta H^{0}[\mathrm{PdSi}]=-120 \mathrm{~kJ} \mathrm{~mol}^{-1}, \Delta \mathrm{H}^{\mathrm{O}}$ being the enthalpies of formation of the clusters calculated from the ideal associated model.

\section{REFERENCES}

(1). R. CASTANet, R. CHASTEl and C. Bergman, Mater. Sei. Eng. (1978), 32, 93-98.

(2). R. CASTANET and C. BERgMAN, Ann. Chimie (1979) 4, 419-23.

(3). R. CASTANeT, J. Chem. Thermodynamics (1979), $11,8,787-91$.

(4). T. KANG and R. CAstanet, J. Less-Common Met. (1977), 51, 1, 125-35.

(5). R. HULTGREN, P.D. DESAI, D.T. HAWKINS, M. GLEISER, K.K. KELLEY and D.D. WAGMAN, "Selected Values of Thermodynamic Properties of the Elements", Am. Soc. Met.. Metals Park, Ohio, 1973.

(6). N.A. VATOLIN, Yu. S. KOZLOV and Yu. O. ESIN, Izvest. Akad. Nauk. SSSR, Metal., 1974, 3, 107-109. 
(7). C. BERGMAN, R. CHASTEL, M. GILBERT and R. CAstANET, High Temp., High Pressures, (1978) 10, 581-90.

(8) C. CHATILLON, A. PATTORET and J. DROWART, High Temp., High Pressures, (1975), 7, $119-148$.

(g) G.R. BELTON and R.J. FRUEHAN, J. Phys. Chem., (1967), 71, 1403-09.

(10) J. BERKOWITZ and W.A. CHUPKA, Trans. N.Y. Acad. Sci. (1960), 79, 1073-78.

(11) N.A. VATOLIN, A.I. TIMOFEEV, D.A. ESIN and E.L. DUBININ, Zh. Fiz. Khim. (1971), 45, 8, $2021-26$.

(12) P.J. BOWLES, H.F. RAMSTADT, F.D. RICHARDSON, J.I.S.I., (1964), 202, 113.

(13) T.G. CHART, High Temp., High Pressures, (1973) 5. $241-52$.

(14) P. Andonov, J. Non-Cryst. Solids, (1976), 22 145- 58 .

(15) K. SUZUKI, T. FUKUNAGA, M. MISAWA and T. MASUMOTO, Mater. Sei. Eng., (1976), 23, 215218.

(16) F. SADOC and J. DIXMIEF, in "The Structure of Non-Crystallins Materials", (1976), Cambridge, Edited by P.H. Gaskell, Taylor and Francis Ltd, London, 1977.

\section{APPENDIX}

The ideal associated model is a limiting case of the regular assuciated model and has been applied to organic and metaliic systems. The equations yielding the thermodynamic functions of formation of the binary systems are the following :

$$
\begin{aligned}
& h^{f}=N_{C} \Delta H^{0}+\left(1-(a+b-1) N_{C}\right)\left(\omega_{A B} X_{A} X_{B}+\omega_{B C} X_{B} X_{C}\right. \\
& { }^{+} \omega_{A C} X_{A} X_{C}
\end{aligned}
$$

$$
g^{f}=h^{f}-T\left(N_{C} \Delta S^{0}+N s^{\text {conf }}\right)
$$

with $\Delta G^{O}=\Delta H^{O}-T \Delta S^{O}=-R T \operatorname{Ln} K$.

$N_{C}$ being the number of clusters, $A_{a} B_{b}$, present in the melt, $N_{A}$ and $N_{B}$ resp. $A$ and $B$,

$\omega_{i j}$ are the residual interactions between the different species,

$X_{i}$ is the molar fraction of $i$ in the ternary system $\Delta H^{\circ}, \Delta S^{\circ}, \Delta G^{\circ}$ and $K$ are respectively the standard enthalpy, entropy, free enthalpy of formation of the cluster and the equilibrium constant.

In such a model based on a localized short range order, we have to define a configurational entropy taking into account this effect instead of using the ideal value $\left[s^{\operatorname{conf}}=-\operatorname{REX}_{i} \operatorname{Ln} X_{i}\right]$.
Thus, an additional constraint which hinders exchange between free species $A$ and $B$ and the clusters $C$, is introduced in the calculation of $g$, total number of permutations: It corresponds to a loss of freedom and leads to lower entropies. g can be written as :

$$
g=\frac{\left(\frac{N n}{a+b}\right) !}{N\left(\frac{n}{a+b}-N_{C}\right) !} N N_{C} ! \times \frac{N\left(n-N_{C}(a+b)\right\} !}{N N_{B} ! N N_{A} !}
$$

where

$N$ is the Avogadro number.

$n$ is the number of moles of the binary system In the case of a two-clusters based model, another species $A_{c} B_{d} \equiv D$ (with $c+d<a+b$ ) has to be added, as well as the corresponding parameters, $\Delta H_{D}^{0}, \Delta S_{D}^{0}, \Delta G_{D}^{0}, K_{D}$.

g can be written as:

$$
\begin{aligned}
g & =\frac{\left(\frac{N_{n}}{a+b}\right) !}{N\left(\frac{n}{a+b}-N_{C}\right) ! N N_{C} !} \times \frac{\frac{N\left(n-N_{C}(a+b)\right)}{a+b} !}{N\left(\frac{(n-N C D(a+b))}{c+d}-N_{D}\right) ! N N_{D} !} \\
& \times \frac{N\left(n-N_{C}(a+b)-N_{D}[c+d)\right) !}{N N_{A} ! N N_{B} !}
\end{aligned}
$$

